$$
\begin{array}{ll}
D R-1027-8 & \text { PPPL-22 } 10 \\
I-21086 &
\end{array}
$$

TOTAL SCATTERING CROSS SFCTIONS AND INTERATOMIC POTENTTALS FOR NEUTRAL HYDROGEN AND HELIUM ON SOME NOBLE GASES

By

D.N, Guzic and S.A. Cohen

APRIL 1985

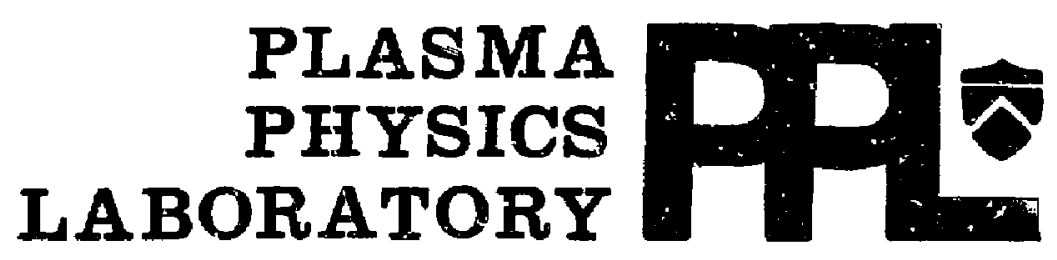




\title{
Total Scatrering Cross Sections and Interatomic Potentials \\ for Neutral Hydrogen and Helium on sone Noble Gases
}

\author{
David N. Ruzic ${ }^{\dagger}$ and Samuel A. Cohen, \\ Plasma Physics Laboratory, Princeton Universi $=y$ \\ Princeton, NJ 09544
}

\begin{abstract}
Measurements of energy-dependent scattering cross sections for 30 to 1900 eV $J$ innident on He, Ne, $A r$, and $K r$, and for 40 to 850 eV He incldent on he, Ar, and $\mathrm{Kr}$ are presented. They are determined by using the charge-exchange efflux from the Princeton Iarge Torug tokamak as a source of $D$ or He, These neutrals are passed through a gas-filled scattering cell and detected by a time-of-flight spectrometer. The cross section for gcattering greater than the effective angle of the apparatug ( $-20 \mathrm{mrad})$ is found by measuring the energy-dependent attenuation of $D$ or He as a function of pressure in the scattering cell. The interatomic potential is extracted from the data.
\end{abstract}

t present address: Fugion Studies Iaboratory, University of Illinois, Urbana, I111nois 61801

\section{DISCLAIMER}

This teport was prepared as an acosont of work sponsared by au agency of the Unired States Government. Neither the United States Government nor any agency thereof, nor any of their employes, makes any parranty, express or implied, or assumes any legal liability or responsibility for the accuracy, completeneas, or usefulaess of any information, apparatus, froduct, or process diselosed, or represents that its use would nol infringe privalely owned righes. Reference herein 10 any specific commencial product, process, of tervice by trade name, trademark, menufacturet, or otherwise dos not nocessarily constitute or imply its enciorsement, recommendation, of Javoring by the Unitod States Government or any agency thereol. The views and apinions of authors expressed hercin do not necessarily atale or reflect those of the Unitod Seales Government or any ogency thereot.

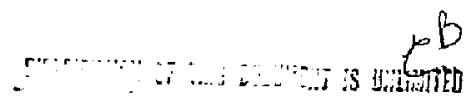


Neutral-neutral cross sections are 1mportant to basic atomic physics. They provide a way to extract the interatomlc potential over a narrow range in interatomic distances and thus check theoretical modeis of atom/atom interactions. From the point-of-view of fusior research, knowledge of certain atomic cross sections increages our understanding of edge efferts, allows 1mproved designg and models of divertors and refined calculations of neutral density profiles. 1 For these applications the differential cross sectior at each energy for each process (elastic, reactive, lonization, etc.) ghould be known. However, total scattering cross sectlons as a function of etiercy do provide the necessary data to calculate first order effects. In the enercy and density range of interegt to magnetic confinemont, the elastic scattering cross section is much larger than all the other neutral-neutral processes. The energy range investigated in this experiment is $30 \mathrm{ev}$ to $1800 \mathrm{ev}$. The potentiais thus determined are in the repulsive wall region, roughly $0.5 \&$ to 2.0 \& depending on the palr. The pairs investigated are: deutertum on helium, neon, argon, and krypton, and helium on helium, argon, and krypton. The technique employed marks the first time a magnetic fusion device has been used to provide basic daja of atom/atom collisions. Spectroscopic studites of electron/aton interactions are, of course, commonly performed in these devices.

The cross sections are determined by passing energetic neutral atoms through a gas-filled scattering cell and monitoring the attenuation as a function of pressure in the cell. A complete description of the apparatus and techniques can be found in Ref. 2. The source of the energetic neutrals is the charge-exchange efflux from the Princeton Iarge Torus (PLT) cokanak. ${ }^{3}$ The PIT tokamak provides 1 -sec "shots" of nearly constant $2 \times 10^{15}$ atoms/cm ${ }^{2}$ s efflux generated by charge exchange of cold gas atoms with hotier plasma 
1ons. The energy spectrum of thege charge-exchange atoms is zoughly Haxwellian with an average energy of 250 ev. The neutrals are all in the ground state because of the velocity-1nduced stark effect on metastable states and the higi decay rate for allowed transitions. The great advantage of uging the PLT tokamak for studying certaln atomic processes is the purtty of the efflux and the "brightness" of the enission in the desired energy range as compared with atoric beam techniques.

The detector of the energetio neutrals is the Low-Energy Neutral-Atom spectrometer (LENS). 4,5 The LENS is a time-oi-flight spectrometer with an energy range of $10 \mathrm{eV}$ to $2000 \mathrm{ev}$ for deuterium. The rinimum detectability threshold for deuterium at $100 \mathrm{eV}$ is $1.0 \times 10^{10}$ atoms/cm ${ }^{2} \cdot \mathrm{eV}^{\mathrm{s}} \cdot \mathrm{ster}$ when the time resolution is 1 msec. 2,6 since the flux over a wide energy range is measured virtually simultaneousiy, and since elastle neutrai/neutral collisions dominate at these energies, $7-10$ the dependence of sross section on energy for a particular pair of atong can be determined during one-second, orders-of-magnitude less time than by other techniques.

Using a pulsed gas valve, a scattering cell between the PLT tokamak and the LENS can be filled with a selected gas within milliseconds. The attainable steady-state pressure range is $1 \times 10^{-4}$ torr to $1 \times 10^{-1}$ torr as measured by a calibrated schultz-Phelps gauge. When a scattering gas of density $\mathbf{n}$ is present in the cell, some of the neutrals from the tokamak that: were directed toward the LENS detector are scattered from the beam. The intensity of neutrals at a given energy, I(E), after traversing a length, $L$, in the scattering gas is simply $I(x)=I_{0}(E) \exp [-n \sigma \sigma(E)]$, where $I_{0}(E)$ is the initial intensity at energy $E$, and $\sigma(E)$ is nominally the cross section at that energy. What is actually measured is $\bar{\sigma}_{s c}(\Sigma)$, the averaged effective-angle-dependent total scattering cross section. it is an averaged 
quantity because the scattering cell has finite dimensions; it is effective-angle dependent because deflections smaller than a certain angle are still detected. Further complications arise from scattering events that add particles into the beam.

Derining the z-axis as the direction along the beam of neutrais, the relationship between the "background" beam intensity observed when no gas is in the scattering cell, $T_{b k g}$, and when a gas is present, $I_{\text {gas }}$ is given by an integral over the entire beam path:

$$
-i n \frac{I_{g a s}}{I_{b k g}}=\int_{0}^{a} n(z) \sigma d z+\int_{a}^{a+b} n(z) \sigma d z+\int_{a+b}^{a+b+c} n(z) \sigma d z
$$

where a is the length of the detector, $b$ is the length of the scattering cell. and $c$ is the length of the dict to the PLT tokanak.

The density, $n(z)$, was calculated at all $z$ ior each pressure using the vacuum system transient simulator (VSTS) code. 11 The code and fiessure gauges show the density in the scattering cell, $\mathbf{n}_{\mathrm{Sc}^{\prime}}$ ig constant. The scattering cross section, $\sigma$, is not constant along $z$ because $\sigma$ 1s a function of the angular transmission of the apparatus. Ietting do( $\theta, \phi) / d \Omega$ be the differential scattering cxoss section and $\theta_{e f}$ be the effective resolution angle, $\bar{\sigma}_{g c}$ is defined:

$$
\bar{\sigma}_{s c}=\frac{1}{b} \int_{a}^{a+b} \int_{0}^{2 \pi} j_{\theta}^{\pi} \frac{d a}{d \Omega}(\theta, \phi) \sin \theta \text { a } \theta d \phi d z
$$

Equation (1) can now be written; 


$$
-2 \frac{I_{\text {gas }}}{I_{b k g}}=n_{s c} \sigma_{s c^{L}}
$$

where $L=b(1+\alpha)$ and

$$
a \equiv \frac{\int_{0}^{a} n(z) \sigma d z+\int_{a+b}^{a+b+c} n(z) a d z}{n_{s c} b \bar{\sigma}_{s c}} .
$$

The correction term, $\alpha$, accounts for scattering outside the scattering cell. It was calculated using the VSTS code and following Amdur and Jordan 2,12 for each pressure and pair of atoms. The value of a was $0.15 \pm 0.015$ for all combinations except for helium on helium where it was $0.20 \pm 0.02$.

The artor in the measured quantity, $\bar{\sigma}_{\mathrm{Sc}^{\prime}}$ is due to uncertainty in effective length, pressure measurement, and counting statistics. Arrival time uncertainty procuces an error in energy. At $100 \pm 5 \mathrm{ev}_{r}$ for example, the uncertainty in effective length is 2.0\%; the uncertainty in pressure meagurement is 5.0k; and the uncertainty due to counting statistics is $7.9 \%$. The counting statistic uncertainty lessens at higher energies, but the unceztainty in energy becomeg greater.

When different pressures of the same gas are used in the scattering cell, ln (I gas $\left./ I_{\mathrm{bkg}}\right)$ should be directly proportional to the pressure if no multiple scattering or experimental artifact ${ }^{2}$ occurs. Figure 1 shows this linear dependence for deuterium incldent on helium. Figures $2 a$ and $2 b$ show $\bar{\sigma}_{s c}$ as a function of energy for all the gas pairs measured. For values of $\bar{\sigma}_{s c}$ to be useful, the effective angle must be known. The calculation ts elaborate for a di vergent beam. 
Two events can change the intensity of a beam of particles when it heads toward a detector through a scattering gas:

(a) Payticles that were going to hit the detector are scattered out of the way. Following Jordan, ${ }^{13}$ the cross section for this 18 called of.

(b) Some particles that were going to miss the detector are scattered into it. This cross section is denoted $\sigma_{\mathrm{p}}{ }^{*}$. When a well-collimated beam is incident on the scatterers, this cross section is 1gnorably small. Here, where the incident beam that will be detected is conically shaped with its apex at the end of the scattering cell and $i$ ts base at the tokamak, $\dot{c}_{p}$ * can be a major perturbation.

The total cross gection determined In this experiment, $\bar{\sigma}_{\mathrm{gc}^{\prime}}$ is:

$$
\bar{\sigma}_{s c}=\frac{1}{b} \int_{b}^{a+b}\left(\bar{\sigma}_{p}-\bar{\sigma}_{p}^{*}\right) d z
$$

If the problem is treated classically, 14 an analytlc exnression for $\bar{\sigma}_{\text {so }}$ can be found assuming the interaction is governed by a spherical potential $V(r)=\mathrm{Kr}^{-3} \cdot 2,12,15,16$ For the energles and masses of the atomle pairs considered, the analytic expresgions for $\bar{\sigma}_{p}$ and $\bar{\sigma}_{p}^{*}$ are:

$$
\sigma_{\mathrm{p}}=\frac{1}{2}\left[\frac{\mathrm{KF}(\mathrm{s})}{E}\right]^{\frac{2}{s}} \int_{0}^{2 \pi} \theta_{\mathrm{d}^{-}} \frac{-2}{\mathrm{~s}} \mathrm{~d} \phi
$$

and 


$$
\sigma_{p}^{*}=\frac{1}{2}\left[\frac{\mathrm{KF}(s)}{E}\right]^{\frac{2}{5}} \int_{\phi_{\min }}^{\phi_{\max }}\left(\theta_{d^{\frac{-2}{3} \min }}-\theta_{d^{\frac{-2}{s}}}\right) d \phi
$$

where $\phi_{\min } \phi_{\max } \theta_{\mathrm{d}^{\prime}} \theta_{\mathrm{d}}$ min' and $\theta_{\mathrm{d} \text { max }}$ refer to scattering angles in the gas cell that are generally functions of position, incldent and azimithal scattering angles, ${ }^{2}$ and

$$
F(s)=(\pi) \frac{1}{2} \frac{\Gamma\left(\frac{s}{2}+\frac{1}{2}\right)}{\Gamma\left(\frac{s}{2}\right)}
$$

Averaging (6) and (7) over the Incident angleg and area of the cell, and substituting them 1nto (5) gives the expression for $\bar{\sigma}_{\mathrm{gc}}$ :

$$
\bar{\sigma}_{3 c}=\pi\left[\frac{K F(s)}{E}\right]^{\frac{2}{3}}\left\langle\theta \frac{-2}{s\rangle}\right.
$$

where

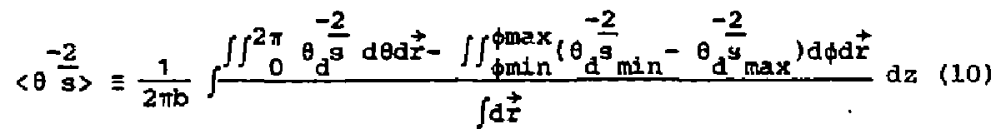

Note that $d \vec{r}$ has four dimensions: two argles to define the Incident beans' dj.rection, and the $x$ and $y$ dimenstons of the scattering cell. The effective scattering angle, tef' can now be defined: 


$$
\theta_{e f}=\left\langle\theta^{\left.-\frac{2}{s}\right\rangle}-\frac{g}{2}\right.
$$

The integral in E. (10) requires a quantum correction for very smal1 $\theta_{a^{5}}$ because the clasgical differential cross section goes to infinity at $\theta \Rightarrow 0$. When the deflection angle becomes smaller than a critical angle, $\theta_{c}$ the clasgical treatment is no longer valid. Critical angles typically have values of 1 to 5 mrad, but clasgical results still mimic the quantum resultg for even lower angleg, 17 A semiclassical cut-off angle, ${ }^{18,19}{ }^{\circ} \mathrm{co}$ somewhat belo' ${ }^{\circ} \mathrm{c}$ was usec in the calculation of $\theta_{\text {ef }}$. Any deflection angle less than $\theta_{\text {co }}$ was treated as $\theta_{c 0^{*}}$ The use of such ai angle was egsential, but its exact value mattered little to the result since the effective scattering angle is much greater than the cut-off angle.

For very simple geometries Fq. (10) can be solved analytically.20 But for the geometry used in this experiment the integral was broken into 81 regions and evaluated ${ }^{2}$ with the aid of tine National Magnetic Fugion Energy Computer Center cray I computer.

To find s from the data, Eq. (9) can be put Into linear fòrm and solved graphically. In principle, $\mathrm{K}$ can also be found, but the error asisociated with the extrapolation to find the intercept value of a logarithmic quanitity is quite large. The valldity limits for the interatomic potentlal's range come from the minimum and maximum scattezing cross section observed. 14 The effective angles and the potential parameters for all the pairs of atoms studied are Iisted in Table 1. The range of possible $\mathrm{K}$ 's is large, The resuyts overlap ab initio theoretical calculations, 21,22 but the error bars are too large to confirm these theoreical results to better than $50 \%$. 
In summary, total scattering cross sections for neutral deuterium on heliuth, neon, argon, and krypton, and for neutral helium on helium, argon, and krypton, have been determined in the energy range of $30 \mathrm{ev}$ to $1800 \mathrm{eV}$ for an effective angle of approximaiely $20 \mathrm{mrad}$. The experiment shows the utillty of the tokamak for studying atomic scattering processes at low energies.

\section{RCXNOWLEDGMENTS}

We wish to thank Cr. J. Hosea for his encouragement and the PLT gtafE and crew for their technical support. Th1s work was supported by the Fannie and John Hertz Foundation and US DOE Contract

I DE-ACO2-76-CHO-3073. 
REFERENCES

1D. post, "The Role of Atonic Collistons In Fuston," in Phystas of Ion-Ian and Electron-Ion Collisions, ed. F. Brouillard and J.W. MCGowan (Plenum Press, NY, 1983).

2D. N. Ruzic, Ph.D. thesis, 2rinceton University, (1984).

3. Grove et al. Proc. 6th Inter. Conf. on physisa and controlled Thermonuclear Fuston Research, Berchtesgaden, West Germany, 21, (1976).

D. E. Voss, Ph.D. thesis, Princeton Untversity. (1980).

5.E. Voss and S.A. Cohen, Rev. Sci. Instrum. 53, 1969 (1982).

6. Ruzie, T.X. Chu, $S_{*}$ Cchen, D. Helfetz, and J. Stevens, BuIl. Am. Phys. Soc. $27,1070(1982)$.

R. Morgenstern, 4. Barat, and D.C. I.orentis, J. Phys. B: 6, L330, (1973).

8 C. Benoit and J.P. Gauyasq, J. Phys. B: 6, I:391, (1976).

9 . Noda, J. Phys. Soc. Japan $41,625(1, \overline{76})$.

10. Van Zyl, T.Q. Le, H. Neumann, and R.C. Amme, Phys. Rev. A. 15,1871 $(1977)$.

11J. Sredniawski, S.s. Hedley, and H, Fishman, Princeton Plasma Fhysiog Laboratory Report PPPL-TM-326, (1979).

12 I. Andur and J.E. Jordan, Adv. Chem. Phys. 10, 29 (1967).

$13 \mathrm{~J} . \mathrm{E}$. Jordan and I. Andur, J. Chem. Phys. 46, 165 (1967).

14 E.A. Mason end J.T. vandersitce, "Atomic and Molecular Processes," D.R. Bates, Ed. (Academic Press, New York, 1962) Chap. 17.

15I. Andur and $H$. Pearlman, J. Chem. Phys. 9, 503 (1941).

$16_{\mathrm{B} . \mathrm{H}}$. Bransden and C.J. Joachain, "Physics of Atoms and Molecules," (Longman, tondon, 1983) Chap. 13.

17E.A. Mason, J.T. Vanderslice, and C.J.G. Raw, J. Chem. Phys. 40, 2153 (1964).

18. W. Ford and J. A. Wheeler, Ann. Phys. 7, 259 (1959).

: 9 R. B. Berngtein, Adv. Chem. Bhys. $53,50(1970)$.

20I. Andur, J.E. Jordan, ana S.0. Colgate, J. Cher. Phys. 34, 1525 (1961).

21 F.D. Wilson and C.L. Bisson, Sandia Laboratories Report SCL-DC-70-45,

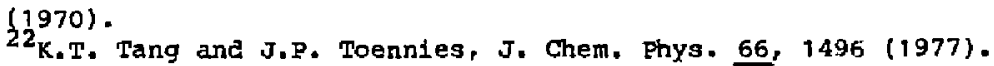


table 1:

\begin{tabular}{|c|c|c|c|c|c|c|c|}
\hline $\begin{array}{c}\text { incident } \\
\text { atom }\end{array}$ & $\begin{array}{c}\text { Earget } \\
\text { atom }\end{array}$ & $\begin{array}{c}\theta_{\text {ef }} \\
\text { (mrad) }\end{array}$ & $\begin{array}{r}9 \\
\pm .05 \\
\end{array}$ & $\begin{array}{r}X(\max ) \\
A^{3} \cdot e V\end{array}$ & $\begin{array}{r}X(\min ) \\
\mathrm{A}^{\mathrm{S}} \cdot \mathrm{eV}\end{array}$ & $\underline{A}_{\text {max }}$ & $x_{\mathrm{n}^{\mathrm{in}}}$ \\
\hline D & $\mathrm{He}$ & $19.5 \pm 2.7$ & 2.60 & 4.02 & 0.662 & 1.29 & 0.33 \\
\hline D & Ne & $22.1 \pm 4.0$ & 3.45 & 14.2 & 3.96 & 2.33 & 0.71 \\
\hline D & $A x$ & $23.9 \pm 5.4$ & 4.45 & 14.9 & 5.06 & 2,19 & 0.81 \\
\hline$D$ & $\mathbf{K r}$ & $24.7 \pm 0.4$ & 5.20 & 12.4 & 4.53 & 1.31 & 0.84 \\
\hline He & $\mathrm{He}$ & $19.5 \pm 2.7$ & 2.60 & 5.74 & 0.946 & 1.18 & 0.38 \\
\hline He & $\mathrm{Ax}$ & $22.6 \pm 4.2$ & 3.70 & 28.4 & 8.6 & 2.39 & 1.06 \\
\hline He & $\mathrm{KI}$ & $24.1 \pm 5.9$ & 4.90 & 47.5 & 16.9 & 2.19 & 1.16 \\
\hline
\end{tabular}

Effectlve scatte-ing angles, ' $\theta$ fef for the total scattering cross sections presented in Eig. 2, and interatomic potential parameters for the form $v(x)=$ $k r^{-9}$. The potentials are valld between $r_{\min }$ and $r_{\max }$. The values of $r$ have about a 10 erroz. 


\section{FIGURE CAPTIONS}

FIG. 1 Comparison of "gas" to "background" charge-exchange efflux ratio vg. pressure for flve energies of incident deuterium neutrals on six different pressures of helium. The linearity of these curves on the semi-log plot indicateg that single-event elagtic scattering is the doninant attenuation process. The slope of these lines is inversely proportional to - $\sigma_{g c^{L}}$

FIG. 2 (a) The error bars for neon and argon at a given energy are the same size as the ones shown for helium at that energy. The krypton extris 15 proportionally larger along the entlre curve. (b) The error bars for drgon and krypton are the same as the ones shown for hellum. 


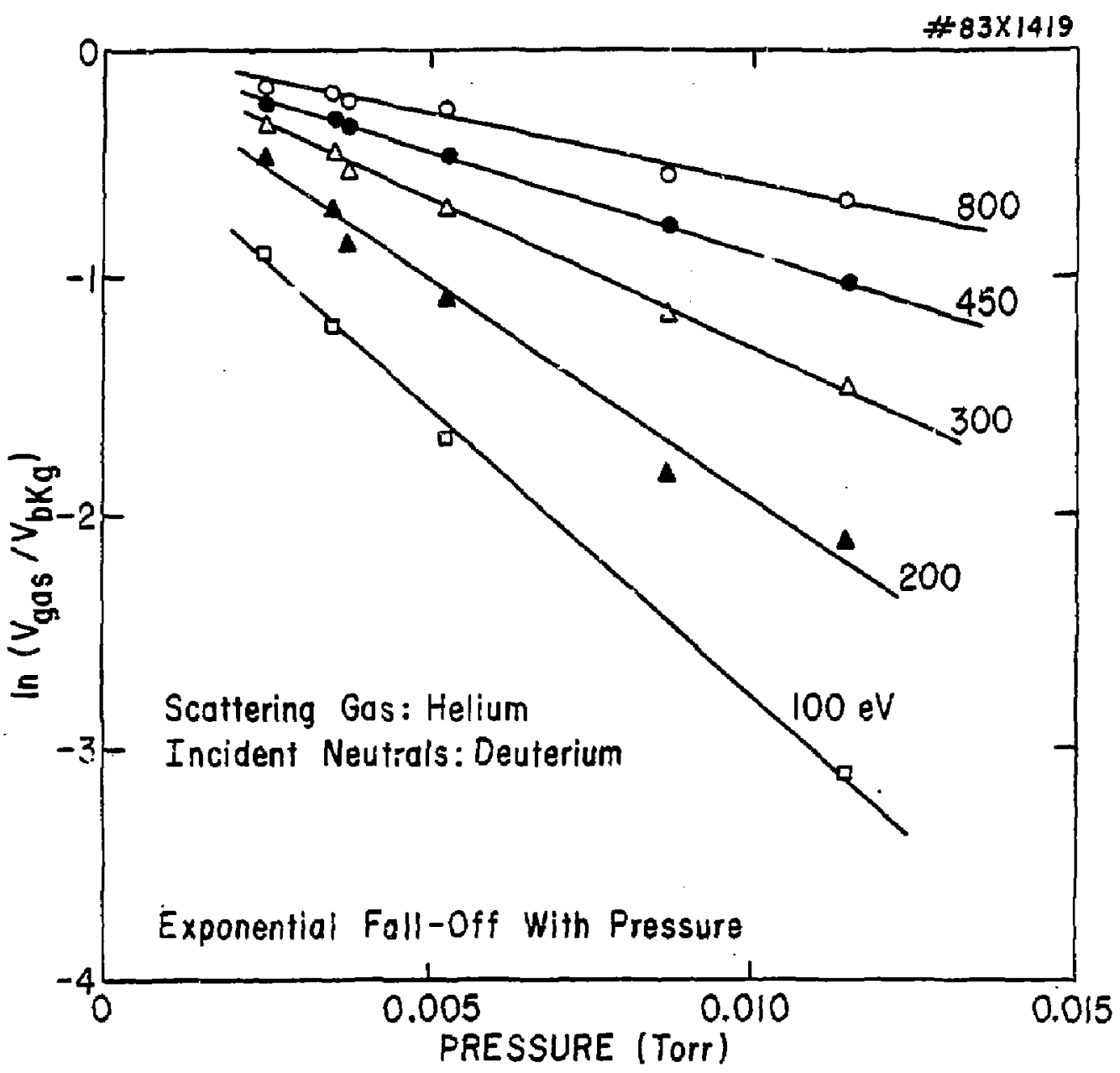

Fig. 1 


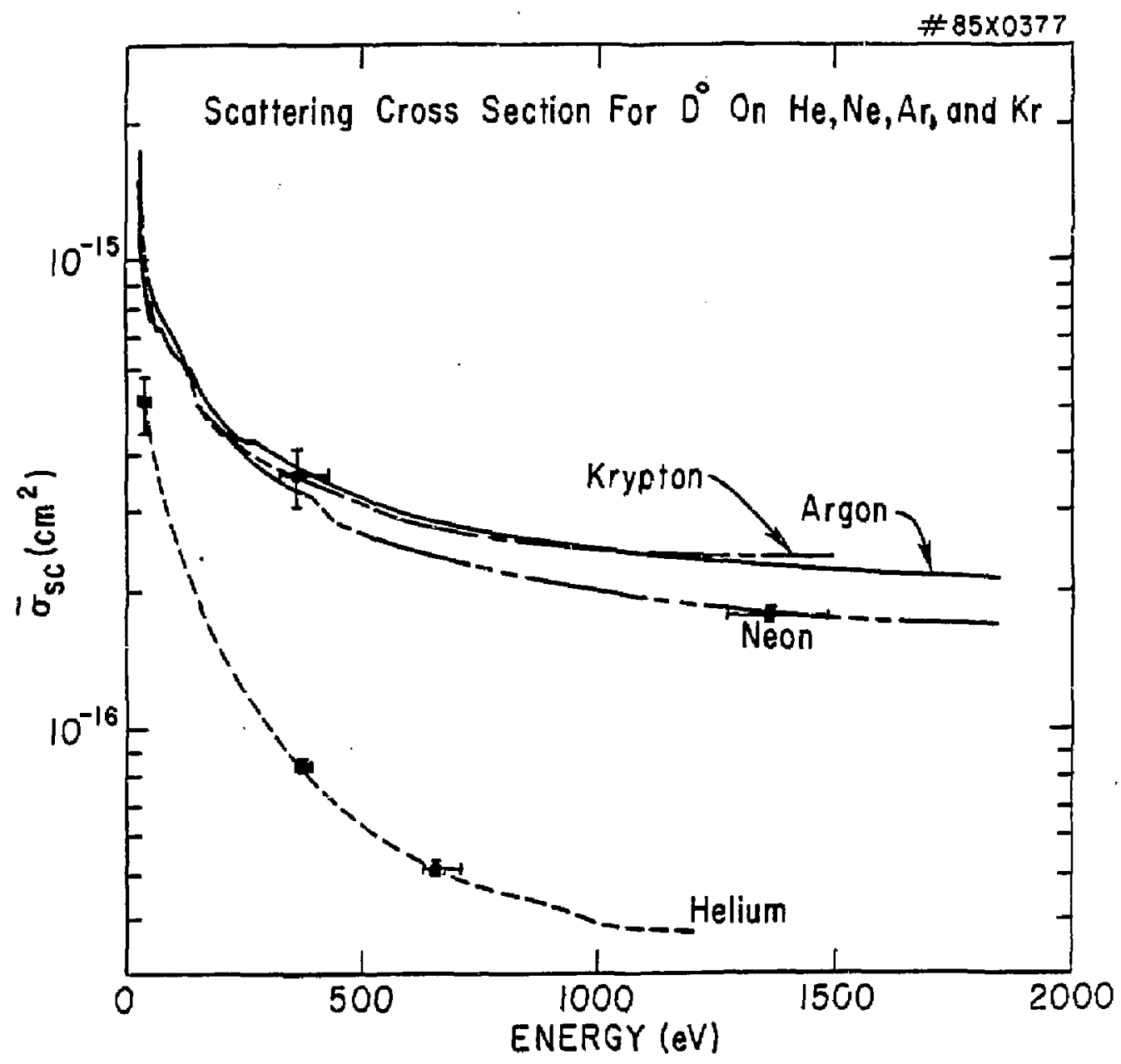

Fig. 2 (a) 


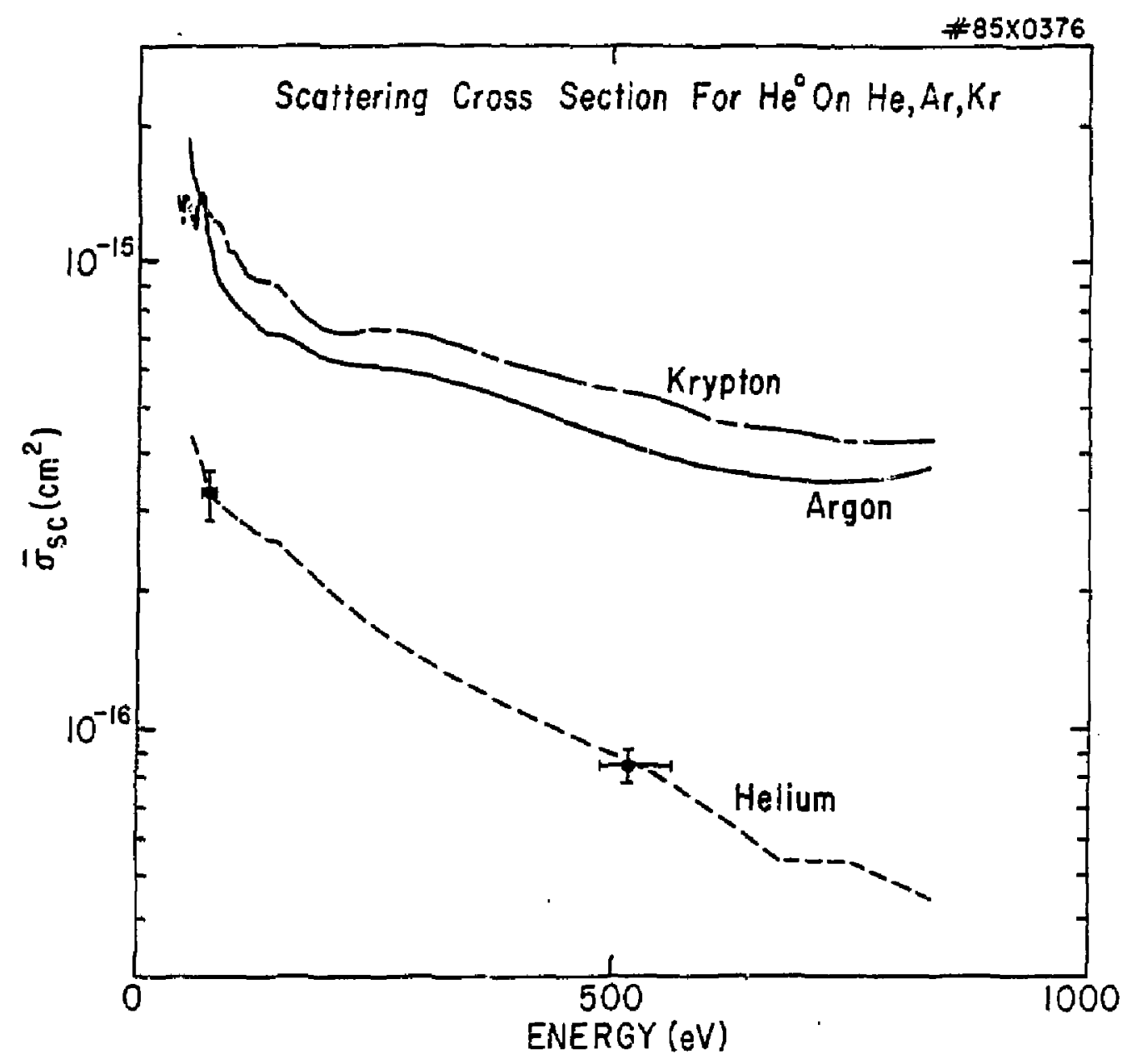

Fig. 2 (b) 
Plasma Res Iab, Austra Nat'l Univ, Asstrath

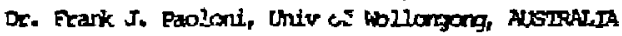
Prot. I.R. Javes, Fliddars Univ., Austrauth

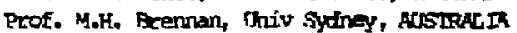
Prof. F. Cap, Inat theo Fhys, Austrua

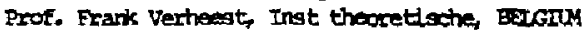
Dt. D. Palunbo, Do XI Fusion Prog, Brigruy Ecole Royale Militaire, Lab de Fhys Plastas, BerchIM Dr. P.K. Stkanaka, Uhiv Estadivi, Eavall. Dr. C.R. James, univ of Alberca, OLPDA pxof. J. Teitmann, Univ of mantreal, curaa Dx. H.M. Seargard Uhiv of Salatwean, CAPDA Prof. S.R. Sreenivasan, Untversity of Calgacy, Chach. Prof. Rdor $\%$. Johnston. INES-Energie, CANDDA Dr. Harres Bamard, Univ Baltish Columbia, CARDA

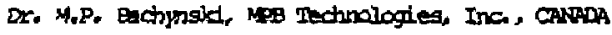
Chalk River, Nucl Lab, CANDA Zhengin Li, si Inst Physics, Cams Iibrary, Tsing tha Univestity, Cinn Librarian, Institati of Fhysico, CHon Inst Plasta Prys, Acadenia sinica, Crum Dr. Peter Lukac, kamengiceho Univ, Caschostomk in The Libzarian, Oulhai Iaborator, Dxass Prof. Solatzan, Observatoire de Nlice, ERAxCE J. Facket, CPN-EQ5, ERANCE AM Dupas Library, AY Dupas Library, RancR Dr. Tom Mul, Acadany Fiblíographis, thav kavg Pregcint Ithrary, Cent Res Irat Phys, Buvafy DF. 5.K. Trethan, Parjat University, IDIA Dr. Indra Mhan Lal Das, Eanaras Hincu Univ, IDDIA DE, I.K. Chayca, Sorth Gujarat Oniv, DDIA Dr. R.K. Ohhajlani, Virram thiv. IDIA Dr. B. Daggupta, Saha Inst, DnIA Dr. P. Kaw, Physical Research Lab, DDIA Dr. Phillig Rogenau, Israel Inst Tech, ISPÄEt Prof. S. Arperman, Tel Autv miversity, ISPAES Pref. G. Rostagni, Univ Di Padovm, IIALY Librarian, Int'l Cer Theo Ehys, IIfLY Mtog Clelta De Palo, Asace Buratha-ENEA, IRALY Biblioteca, del orR bupAtor, ITHY

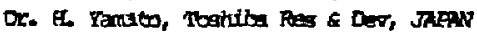
Direc. Tept. Ig. 'lokanak Dev. JAERI, JPAN Prot. Stohisuki Imcue, Ukiversity of Itkyo, JAFAN Pesearch Info Center, Nagoja University, JAPAN Frof. Kyoji Nishikana, Univ of Hiroshima, JAFAN Prof. Sigeru Mori, JREex, IAPAN Tibcary, Kyoto Oniversity, JAFAN Prof. Ichiro Kankand, Nihon thio, JAPAN Prof. Satoshi Itoh, Kynahn Untwersity, JAFN Dr. D.I. Choi, Adv. Inst Sai \& Tech, KOREA Teot Info Divlaton, KAERI, KORER Bibliotheek, Fom-Inst Voor Plaan, NeIrHerchinos
Prcf. 8.5. Liley, University of raikato, NES zEATAND

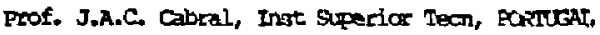
DC. Oetavian Betus, AL $i$ GRA University, ROMANIA Prof. M.A. Jeliberç, Jolversity of Natal, SO ARRICA Dr. Johan de V1llisers, Plagna Fhysics, Mxor, SO AFRICA Fusion Div, Ltorary, JD, SFADN

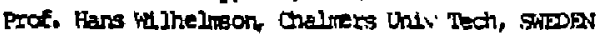
Dr. Iengyt StenfIo, Oriversity of CATA, SHEDEN Whraxy, Royal Inat Tech, SWDev

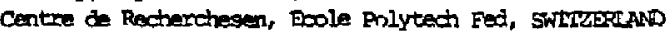
Lr. Y.T. Toldk, Khadiov Ehys Tect Ins, ISSR Dr. D.D. Ryutov, Sibertan RCad SCi, USSR DF. G.A. Elisecy. Kurchatur Institute, USSR DF. V.A. Glukrikh, Inst Dlectro-Enyaical, USSR Instibute Gen. Physlos, LSSR Prof, T.J.M. Sord, Univ College $N$ wales, WALx

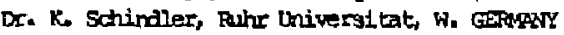
Nuclear Res Estob, Julich Ltd, W. Gorasy Iibrartan, Mex-Pland institut, w, Gerewn: Bibliothex, Ingt Plasmaforschung, W. GEFAIS Prof. R.k. Janev, Inst Phys, Yuoosiavia 